\title{
An examination of portrayals of smoking in graphic novels/ comic books: A picture is worth a thousand words
}

\author{
Daisy Houghton', Frank Houghton ${ }^{2}$
}

\begin{abstract}
INTRODUCTION Smoking continues to extract an unacceptably high toll in Ireland in terms of both mortality and morbidity. Therefore, attention needs to focus on examining pro-smoking influences on teenagers and young adults, as most smokers start smoking before the age of 21 years. Given that this critical period is one of identity formation and assertion of adulthood, it is useful to look at media representation of smoking. One form of increasingly pervasive media that may require further examination is that of the portrayal of smoking in graphic novels. The broad appeal of graphic novels has been well noted, particularly to those aged under 35 years.

METHODS This research examined a random selection of ten graphic novels chosen from the main library in a provincial Irish City. The novels were examined on a panel-by-panel basis for images of smokers. Smokers were coded by gender. RESULTS Analysis identified a total of 526 panels depicting smoking. Substantial variation was noted in the number of smoking images between novels, varying from 0 to 267. A dramatic difference in the number of male to female smokers was observed, the ratio being approximately 17:1.

CONCLUSIONS Graphic novels must be considered as a potentially significant source of portrayals of smoking to adolescent and young adult readers of this form of literature.
\end{abstract}

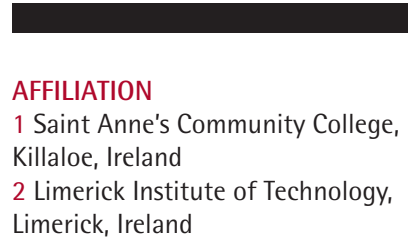

Limerick, Ireland

\section{CORRESPONDENCE TO \\ Frank Houghton. Limerick Institute of Technology, Limerick, V94 EC5T, Ireland. \\ E-mail: frank.houghton@lit.ie}

\section{KEYWORDS}

smoking, adolescents, young adults, Ireland, graphic novels

Received: 11 March 2020 Revised: 25 May 2020

Accepted: 26 May 2020

\section{INTRODUCTION}

Smoking continues to extract an unacceptably high toll in Ireland in terms of both mortality and morbidity, as well as through its financial burden ${ }^{1}$. Despite recent declines in smoking rates in Ireland ${ }^{2}$, the 2025 target of a smoking rate of less than $5 \%$, which would make Ireland in its government's eyes 'smoke-free's, appears decades ${ }^{4}$, or more ${ }^{5}$, away. Recent evidence suggests an overall adult smoking rate of $17 \%$ in Ireland, with a male rate of $19 \%$ and a female rate of $16 \%$. Irish smoking rates are highest among those aged 25-34 years, where the rate is $26 \%^{2}$. Given the successful adoption of many elements of the World Health Organization's (WHO) Framework Convention on Tobacco Control (FCTC) in Ireland, it is important to explore where pro- smoking messages may originate. In line with FCTC guidelines, sponsorship and advertising of tobacco products is illegal in Ireland, alongside a host of other measures including significant taxation and the mandatory introduction of both combined text and graphic anti-tobacco warnings and plain packaging ${ }^{6}$.

Particular attention needs to focus on examining pro-smoking influences on teenagers and young adults, as most smokers start smoking before the age of 21 years with many starting in their teens ${ }^{7,8}$. Given that this critical period is one of identity formation and assertion of adulthood, it is useful to look at media representations of smoking. An extensive body of research has identified alarming links between Big Tobacco and the media9,10. For example, a close relationship between the tobacco 
industry and the film industry dating back as far as 1927 has been identified ${ }^{10}$. In addition, Chapman and Davis ${ }^{9}$ note payments by Philip Morris of $\$ 42500$ to ensure the placement of Marlboro in the movie Superman II, and a similar payment by Liggett of $\$ 30000$ to place Eve cigarettes in Supergirl. The involvement of Big Tobacco in such activities is not surprising. A significant body of evidence has determined the impact of such portrayals in movies and TV on youth initiation to tobacco use $\mathrm{e}^{11-14}$. The use of print media to advertise tobacco products has also been examined in-depth, with a specific focus on magazines ${ }^{15-18}$. It should be noted that most of this analysis, with few exceptions ${ }^{19}$, has been conducted in the US.

One form of increasingly pervasive media that may require further examination is that of the portrayal of smoking in graphic novels/comic books ${ }^{20}$. Tabachnick ${ }^{21}$ defines a graphic novel as 'an extended comic book, written by adults for adults'. It is important to note that the readership of graphic novels has long since moved beyond an 'odd', or 'anorak' status ${ }^{22}$ and into the mainstream ${ }^{23}$. It is interesting to note that in France and Belgium comic/graphic novels have had a strong readership, and not just among children, for many years. In 2017 for example, the graphic novel Astérix 37: Asterix et la Transitalique, was the bestselling book in France, selling almost 1.6 million copies in that year alone ${ }^{24}$.

Analysis of readership from a library-based examination conducted in the US indicated the most common readers of graphic novels were youths aged 12-15 years, with the broader $10-18$ years age group generally being interested in this form of literature ${ }^{25}$. Research commissioned by the (UK) Royal Society of Literature, based on a nationally representative sample of almost 2000 adults aged $\geq 15$ years in Great Britain, found that $6 \%$ of people had read a comic/graphic novel in the past 6 months $^{26}$. It is unfortunate that further details by age or gender were absent from this report. Another examination of the age group 8-18 years in the UK found that roughly $26 \%$ of this group read comics/comic books/graphic novels. This figure was remarkably consistent from 2010-2015 ${ }^{27}$. Extensive research failed to identify relevant readership data for comic/ graphic novels for Ireland. However, in many ways, the similarities between the UK and Ireland outweigh their differences, and so it can broadly be assumed that Irish rates of graphic novel readership are probably very similar to those of the UK.

Evans and Gaudet ${ }^{28}$ describe the readership of graphic novels as 'young and male', while Stewart ${ }^{22}$ states that 'the majority of graphic novel fans are in their late teens to early $30 \mathrm{~s}$. The format is also attracting a growing number of women. The broad appeal of graphic novels has been well noted ${ }^{29,30}$, as well as their attraction to 'reluctant readers' ${ }^{31}$. The demographics of this readership group is crucial in terms of smoking initiation. As noted above, the smoking rate among the cohort aged 25-34 years is the highest of any group in Ireland, with, as noted above, most smokers starting their habit in their teens or early twenties ${ }^{7,8}$.

A growing analytical literature exists around contemporary graphic novels. Graphic novels have, for example, been studied for depictions of violence ${ }^{32}$, the portrayal of disability ${ }^{33}$, and depictions of self-harm ${ }^{34}$. An extensive literature has also examined graphic novels as vehicles for health education ${ }^{35,36}$ and health promotion ${ }^{37}$. The potentially adverse impact of graphic novels on health behaviours has also been examined. Recent research by Lee and DeJong ${ }^{38}$, for example, builds on earlier analysis examining portrayals of smoking in contemporary Japanese Manga graphic novels ${ }^{39}$. Although this research identified a decline in depictions of smoking in more modern Manga comics, the continuing portrayal of smoking remains a serious concern ${ }^{38}$. As Bouissou ${ }^{40}$ comments, to export comics is also to export ideology and value systems.

It must be remembered that it is not accidental that Manga characters are routinely portrayed as heavy smokers. Manga as a genre has consistently and deliberately challenged the spectrum of Japanese societal norms, from respect for parents to cannibalism $^{40-41}$. This is in stark contrast to the Ecole Franco-Belge school that dominated comic book/ graphic novel production in Europe and produced well known and non-controversial examples such as Tintin and Asterix. Similarly, the USA produced 'safe' comic products such as Mickey Mouse ${ }^{42-44}$. As Bouissou ${ }^{40}$ notes 'the American cartoons, after struggling with the stringent constraints of the Comics Code for half a century, gradually 
became emasculated. The readers were tired of no violence, no sex, no police-bashing, no smoking and 'no nothing' ${ }^{40}$. Therefore, although the routine depiction of smoking in Manga is not surprising, the prevalence of smoking depictions in contemporary graphic novels from both Europe and North America is unknown.

It is important to note that representations of smoking in the media are essentially a form of propaganda that perform the three 'Rs' of cultural transmission. That is, they can serve to reflect, reinforce and reproduce particular cultural patterns, in this case around smoking. Following on from the recent examination by Lee and DeJong ${ }^{38}$ of smoking portrayals in Manga, this research aimed to examine portrayals of smoking in a broad spectrum of graphic novels.

The main aim of this research was to explore the volume of smoking portrayals in a random selection of graphic novels. As noted above, a significant body of research has identified the incontrovertible impact of such imagery on smoking rates. A secondary aim was to explore gender differences in such portrayals of smoking. Smoking rates among young females have increased dramatically in recent years, and yet it is clear that a gender bias in anti-tobacco initiatives exists, focusing more on males than females ${ }^{45,46}$. In addition, the academic literature has noted a growth in more female oriented graphic novels, female readers of this genre, and feminist analysis of this art form ${ }^{47,48}$. A third aim of this research was to explore anti-smoking messages or negative portrayals of cigarettes. The fourth and final aim of this research was to provide a brief overview of how smoking is portrayed in the graphic novels examined.

\section{METHODS}

A random selection of ten graphic novels was opportunistically chosen from the general section of a main library in a provincial Irish City. Irish smoking rates compare relatively well with many European Countries ranking 13 th out of 48 countries in a recent WHO Europe Report ${ }^{49}$. A library collection was examined because, leaving aside transport issues, there is no fee to join or borrow books from public libraries in Ireland. Both joining fees and late-return fines were abolished in Ireland in recent years.

The library contained 183 unique titles in the main section that were designated graphic novels in the online catalogue and co-located. The random selection therefore represented a $5.5 \%$ sample. The chosen graphic novels were then examined on a panel-by-panel basis for examples of tobacco use. This included tobacco in the form of cigarettes, cigars, cigarillos, pipes, hookah and exhaled tobacco smoke. Each panel was examined and coded to indicate if it contained an image of: 1) one or males smoking; 2) one or more females smoking; 3 ) one or more males and females smoking; and 4) one or more other/indeterminate gender smoking. The panels were also examined for anti-smoking messages, or negative depictions of smoking or cigarettes. The number of panels per page varied from 1 to 10 or more, although 4 to 8 was standard. Two graphic novels were randomly selected and coded by both researchers to ensure inter-rater reliability. A 100\% concordance in these dual examinations was noted.

Estimating the readership of these graphic novels, to help gain insight into the impact of tobacco portrayals, is notoriously difficult. Irish libraries do not keep a digital record of how many times a book has been checked out. Similarly, sales figures often only relate to one jurisdiction, one language, and one format, and are often only available for when a publication is near the top of sales league tables. Even when sales or library borrower figures are known, it is impossible to know exactly how often a book is read, if at all. Books may be ignored, read, re-read, swapped, re-sold, borrowed, given away, or shared numerous times, or not at all. Readership calculations for graphic novels are further complicated by the fact that the novels themselves are routinely compilations of individual comic issues. Therefore, attempts to analyse sales figures using just one metric, i.e. comic issue sales or graphic novel sales, undoubtedly underestimate the true sales volume. In the absence of any 'concrete' data, Table 1 attempts to provide a more narrative description of the popularity of the ten chosen graphic novels, incorporating sales statistics, where available.

\section{RESULTS}

As can be seen from Table 2, analysis identified substantial variation in the number of portrayals of smoking in individual panels ranging from 0 to 267 , with a mean per novel of $52.6(\mathrm{SD}=81.6)$. It is 


\section{Table 1. Narrative description of sales/success to indicate potential readership}

\begin{tabular}{|c|c|}
\hline Title & Description \\
\hline $\begin{array}{l}\text { 1. Batman Zero } \\
\text { Year - Dark City }\end{array}$ & $\begin{array}{l}\text { This text involves the very popular DC Comics character Batman and its authors include well known writers such } \\
\text { as Scott Snyder and James Tynion IV. Sales from North American Comic Book Shops reached a high of } 6770 \text { in } \\
\text { October } 2014 \text { according to Comichron.com, making it the 5th best-selling graphic novel that month. }\end{array}$ \\
\hline $\begin{array}{l}\text { 2. DIAL H - Into } \\
\text { You }^{51}\end{array}$ & $\begin{array}{l}\text { This is a compilation graphic novel produced by the leading comic firm DC Comics. This series revisits ideas initially } \\
\text { used in both } 1966 \text { and 1981. In } 2012 \text { alone Comichron.com estimated } 44500 \text { Dial H comics were sold from North } \\
\text { American Comic Book Shops. }\end{array}$ \\
\hline $\begin{array}{l}3 . \\
\text { Transmetropolitan } \\
\text { - Back On The } \\
\text { Street }^{52}\end{array}$ & $\begin{array}{l}\text { This text was created by Warren Ellis and Darick Robertson for DC Comics. In } 2010 \text { alone Comichron.com noted } \\
\text { sales of } 5600 \text { of these graphic novels, ranking its sales in 106th place in North American Comic Book Shops. Parts } \\
\text { of this story were originally printed in 1997, with the compilation graphic novel being reprinted four times. The } \\
\text { graphic novel has also inspired a variety of merchandise, and translated versions of the graphic novel in Spanish } \\
\text { and German were also printed. }\end{array}$ \\
\hline $\begin{array}{l}\text { 4. Hellblazer - } \\
\text { Hooked }^{53}\end{array}$ & $\begin{array}{l}\text { The main character John Constantine, aka Hellblazer, was created for DC Comics by Alan Moore and Stephen R. } \\
\text { Bissette. In } 2010 \text { alone Comichron.com recorded sales of } 3200 \text { of these graphic novels, ranking it in 301st place } \\
\text { North American Comic Book Shops. Evidence of its success and popularity can be seen in that the comic series ran } \\
\text { for } 300 \text { issues, before being re-cast and continued. Two films related to the main character have been produced, } \\
\text { one staring the well-known actor Keanu Reeves. }\end{array}$ \\
\hline $\begin{array}{l}\text { 5. Sin City - A } \\
\text { Dame To Kill For }{ }^{54}\end{array}$ & $\begin{array}{l}\text { This text has been reprinted multiple times, as well as being translated into Spanish. According to Comichron.com } \\
\text { this novel was the third best-selling graphic novel in } 2005 \text { in North American Comic Book Shops. According to the } \\
\text { same source it was still in the top } 400 \text { graphic novels sold in } 2010 \text {. This text was remade as an American action } \\
\text { crime film in } 2014 \text { grossing } \$ 39 \text { million at the box office. }\end{array}$ \\
\hline $\begin{array}{l}\text { 6. Gotham Central } \\
\text { - Unresolved } \\
\text { Targets }^{55}\end{array}$ & $\begin{array}{l}\text { This text features Gotham, the infamous city in many DC Comics. It was written by leading lights, Ed Brubaker and } \\
\text { Greg Rucka. According to Comichron.com it recorded } 3406 \text { sales in the month of May } 2006 \text { alone, making it the } \\
\text { 18th most sold graphic novel in North American Comic Book Shops that month. }\end{array}$ \\
\hline $\begin{array}{l}\text { 7. Walking Dead } \\
\text { Volume 4: The } \\
\text { Heart's Desire }^{56}\end{array}$ & $\begin{array}{l}\text { This series was created by Richard Kirkman for Image Comics. The series ran for } 193 \text { issues and, according to } \\
\text { Comichron.com, was the seventh best-selling graphic novel in North American Comic Book Shops in } 2012 \text {. Sales } \\
\text { were undoubtedly fostered by the hit TV series, The Walking Dead, that has already commissioned an 11th season, } \\
\text { and several other spin-off series and merchandise. }\end{array}$ \\
\hline $\begin{array}{l}\text { 8. Walking Dead } \\
\text { Volume 2: Miles } \\
\text { Behind Us }\end{array}$ & $\begin{array}{l}\text { This series was created by Richard Kirkman for Image Comics. The series ran for } 193 \text { issues and according to } \\
\text { Comichron.com was the second best-selling graphic novel in North American Comic Book Shops in 2012. Sales } \\
\text { were undoubtedly fostered by the hit TV series, The Walking Dead, that has already commissioned an } 11 \text { th season, } \\
\text { and several other spin-off series and merchandise. }\end{array}$ \\
\hline $\begin{array}{l}\text { 9. ABC Warriors: } \\
\text { The Shadow }\end{array}$ & $\begin{array}{l}\text { ABC Warriors are characters from the popular British comic } 2000 \text { AD. These characters have been running now for } \\
\text { over } 40 \text { years. }\end{array}$ \\
\hline
\end{tabular}

Warriors ${ }^{58}$

10. War Brothers: This graphic novel is based on the acclaimed novel of the same title, winner of a 2009 Arthur Ellis award.

The Graphic

Novel ${ }^{59}$

interesting to note that the two graphic novels from the dystopian zombie apocalyptic series, the Walking Dead $^{56,57}$, each contained no images of smoking, while the dystopian cyber-punk graphic novel, Transmetropolitan ${ }^{52}$, contained the most.

As a form of graphic novel, it is notable that those examples from the noir genre, Sin City - A Dame To Kill For ${ }^{54}$, and Gotham Central - Unresolved Targets ${ }^{55}$ included 112 images of smoking in total. The noir genre routinely portrays the dark, gritty and seedy underworld of a corrupt society, often modelled around large US cities in the 1930-1950 era.
The difference in the number of portrayals of smoking by gender was striking. A total of 481 separate panels showed one or more males smoking, while the equivalent figure for females was only 19. Just 10 panels detailed both males and females smoking, while 16 panels featured robots smoking (Table 2). None of the novels examined featured any negative portrayals of smoking, such as depictions of lung cancer, smoking related bad breath, smoking related fire risks, or financial hardship caused by a smoking habit. Similarly, none of the novels included overt anti-smoking health promotion messaging, as 
Table 2. Number of panels with smoking portrayals by gender in a random selection of ten graphic novels

\begin{tabular}{|c|c|c|c|c|c|c|}
\hline Tille & Pages* & Vale & Female & $\begin{array}{l}\text { Vale \& } \\
\text { Female }\end{array}$ & $\begin{array}{l}\text { Gender } \\
\text { neutral }\end{array}$ & Total \\
\hline 1. Batman Zero Year - Dark City (2014) ${ }^{50}$ & 260 & 7 & 0 & 0 & 0 & 7 \\
\hline 2. DIAL H - Into You (2013) $)^{51}$ & 88 & 17 & 0 & 0 & 0 & 17 \\
\hline 3. Transmetropolitan - Back On The Street $(2009)^{52}$ & 148 & 257 & 1 & 9 & 0 & 267 \\
\hline 4. Hellblazer - Hooked (2010) $)^{53}$ & 132 & 91 & 1 & 0 & 0 & 92 \\
\hline 5. Sin City - A Dame To Kill For (1995) $)^{54}$ & 212 & 27 & 17 & 1 & 0 & 45 \\
\hline 6. Gotham Central -Unresolved Targets $(2006)^{55}$ & 195 & 67 & 0 & 0 & 0 & 67 \\
\hline 7. Walking Dead Volume 4: The Heart's Desire $(2012)^{56}$ & 148 & 0 & 0 & 0 & 0 & 0 \\
\hline 8. Walking Dead Volume 2: Miles Behind Us $(2012)^{57}$ & 140 & 0 & 0 & 0 & 0 & 0 \\
\hline 9. ABC Warriors: The Shadow Warriors (2009) ${ }^{58}$ & 162 & 15 & 0 & 0 & 16 & 31 \\
\hline 10. War Brothers: The Graphic Novel (2013) ${ }^{59}$ & 174 & 0 & 0 & 0 & 0 & 0 \\
\hline
\end{tabular}

*Including cover.

Figure 1. Examples of portrayals of smoking in a random selection of graphic novels
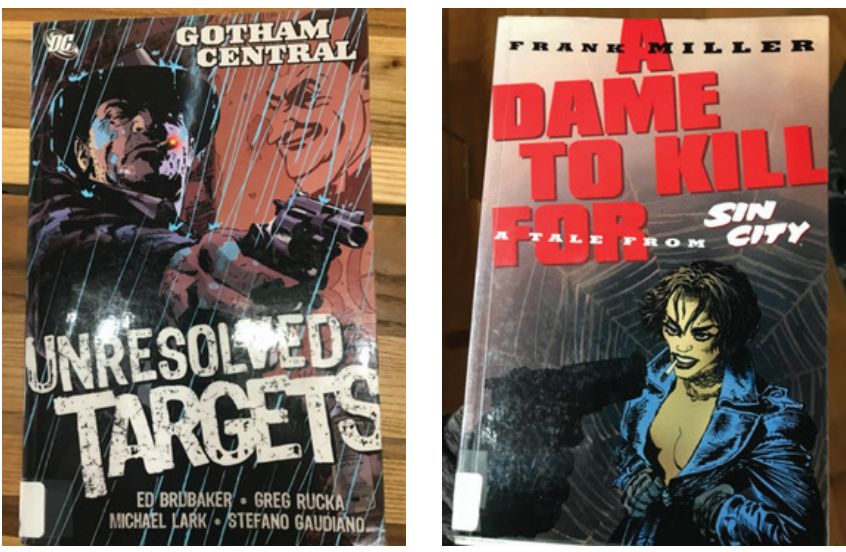

usually featured on packets of cigarettes.

Figure 1 details four examples of portrayals of smoking in the selection of graphic novels examined. Where smoking was portrayed in the graphic novels examined, it was often a strong feature of central characters. For example, in Transmetropolitan Back on the Street ${ }^{52}$, the main character, Spider Jerusalem, is a habitual smoker and is the antihero of the novel, fighting corruption among the governing elite. The main character of Hellblazer Hooked $^{53}$, John Constantine, is an avid smoker and plays a remarkably similar role. In Sin City - A Dame to Kill For, the main smoker is Ava Lord, the leading character, a femme fatal and ruthless seductress ${ }^{54}$. Thus, smoking in these graphic novels was generally typified as the pursuit of iconic leading characters, rebels against conventional norms, who are willing to break the rules in order to succeed.
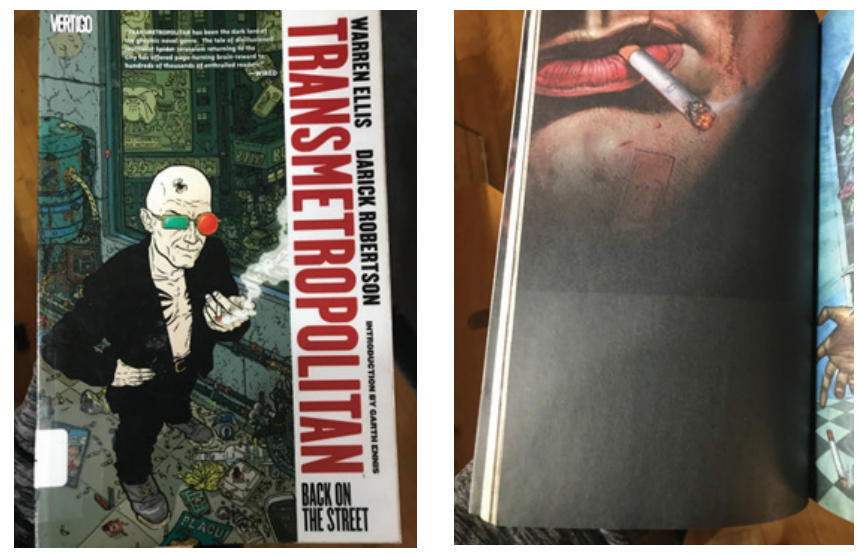

\section{DISCUSSION}

This randomly selected cross-section of ten graphic novels contained a total of 526 panels depicting smoking. As such, graphic novels must be considered a potentially significant source of portrayals of smoking to adolescent and young adult readers of this form of literature. As has been found in other similar research ${ }^{38}$, males were the main characters shown to be smoking, the main exception being the leading femme fatal character in Sin City - A Dame to Kill For ${ }^{54}$. Although there were over 500 portrayals of smoking, not once were anti-tobacco behaviours or dialogue in evidence. Research indicates that this absence of negative portrayals of smoking in the media has long been an issue $\mathrm{e}^{60,61}$. Smoking images, where they were included, tended to depict strong independent characters railing against the 'system', and willing to break rules to achieve their ends. 
Given what we know about the impact of media representations of smoking on youth initiation into smoking, these depictions inevitably raise serious and well-founded concerns about concomitant youth attitudes, beliefs and behavioural decisions ${ }^{11-18}$. Despite the body of evidence demonstrating the longterm impact of exposure to portrayals of smoking in the media and smoking prevalence ${ }^{11-18}$, it is of course impossible to definitively suggest that these images cause adolescents and young adults to smoke. Further research, perhaps through the use of a format such as focus groups, could usefully explore how these age cohorts interpret and understand these images.

It is important to note that the focus of this analysis was smoking. This was done because smoking is the leading cause of preventable mortality and morbidity globally, responsible for over 7 million deaths annually. However, from a health promotion perspective, graphic novels could equally be examples to explore drug and alcohol use, portrayals of firearms, violence, and gambling.

\section{Limitations}

It must be acknowledged that this study involved a relatively small random sample of just ten graphic novels chosen from just one library, albeit the largest branch in a regional city. Future research should include a larger, and ideally an international sample of graphic novels available in public libraries.

\section{CONCLUSIONS}

It is important that public health/tobacco control advocates engage with the artists, writers and producers of graphic novels to promote alternative positive role models and behaviours, as well as to decrease smoking portrayals ${ }^{62}$. A parental advisory warning on such novels is also appropriate. A potential model for similar types of warnings, that have demonstrated some positive impact, often aimed at parents, may be seen in relation to healthy eating, notably focussing on high sugar food and drinks ${ }^{63}$. Finally, given the variation in the number of portrayals of smoking in the different genres of graphic novel captured in this assessment, further research is required to explore this in-depth. This research should cover both the cyberpunk and the crime noir genres of graphic novels to determine if the snapshot findings from the present research are truly representative.

\section{REFERENCES}

1. American Cancer Society. The Tobacco Atlas: Ireland. 2020 at https://tobaccoatlas.org/country/ireland/. Accessed March 2, 2020.

2. Government of Ireland. Healthy Ireland: Summary Report 2019. Dublin, Ireland: Department of Health; 2019. https:// assets.gov.ie/41141/e5d6fea3a59a4720b081893e11fe299e. pdf. Accessed May 25, 2020.

3. Government of Ireland. Tobacco Free Ireland. Dublin, Ireland: Department of Health; 2013. https://assets.gov. ie/19465/0c99a96e05c54b249c7d53b93b17437c.pdf. Accessed May 25, 2020.

4. Li S, Levy D, Clancy L. Tobacco Free Ireland 2025: SimSmoke prediction for the end game. Tob Prev Cessation. 2018;4(June). doi:10.18332/tpc/91427

5. Houghton F, O'Doherty D, McInerney D, Duncan B. Response to Tobacco Free Ireland 2025: SimSmoke prediction for the end game. Tob Prev Cessation. 2019;5(January). doi:10.18332/tpc/102277

6. Health Services Executive. Tobacco Free Ireland Programme Plan 2018-2021. Dublin, Ireland: Health Services Executive; 2018. https://www.hse.ie/eng/ about/who/tobaccocontrol/hse-tfi-2018-2021plan/\#: :text=This\%20national\%20implementation $\% 20$ plan $\% 20$ (2018, next $\% 20$ four $\% 20$ years $\% 20$ are $\% 20$ to $\% 3 \mathrm{~A} \&$ text $=$ Support $\% 20$ people $\% 20$ to $\% 20$ quit $\% 20$ and $\% 20$ treat $\% 20$ tobacco $\% 20$ dependence $\% 20$ as $\% 20$ a $\% 20$ health\%20care\%20issue. Accessed May 25, 2020.

7. Evans D, O'Farrell A, Sheridan A, Kavanagh P. Youth Smoking in Ireland: A special analysis of the Health Behaviour in School-aged Children (HBSC) study. Dublin, Ireland: Health Service Executive; 2018. https:// www.lenus.ie/bitstream/handle/10147/623073/youthsmoking-report.pdf?sequence $=1 \&$ cisAllowed $=y$. Accessed May 25, 2020.

8. Sheridan A, O'Farrell A, Evans D, Kavanagh P. Adult Smoking in Ireland: A Special Analysis of the Healthy Ireland Survey and The Irish Longitudinal Study on Ageing (TILDA). Dublin, Ireland: Health Service Executive; 2018. https://www.hse.ie/eng/about/who/ tobaccocontrol/adult-smoking-in-ireland-a-specialanalysis-of-the-healthy-ireland-survey-and-the-irishlongitudinal-study-on-ageing-tilda.pdf. Accessed May $25,2020$.

9. Chapman S, Davis RM. Smoking in movies: is it a problem? Tob Control. 1997;6(4):269-271. doi:10.1136/tc.6.4.269

10. Lum KL, Polansky JR, Jackler RK, Glantz SA. Signed, sealed and delivered: "big tobacco" in Hollywood, 1927-1951. Tob Control. 2008;17(5):313-323. doi:10.1136/tc.2008.025445

11. Sargent JD. Smoking in movies: impact on adolescent smoking. Adolesc Med Clin. 2005;16(2):345-370. doi:10.1016/j.admecli.2005.02.003

12. Sargent JD, Hanewinkel R. Impact of media, movies and TV on tobacco use in the youth. In: The 
Tobacco Epidemic. Basel, Switzerland: Karger; 2015. doi:10.1159/000369482

13. Charlesworth A, Glantz SA. Smoking in the movies increases adolescent smoking: a review. Pediatrics. 2005;116(6):1516-1528. doi:10.1542/peds.2005-0141

14. Tickle JJ, Sargent JD, Dalton MA, Beach ML, Heatherton TF. Favourite movie stars, their tobacco use in contemporary movies, and its association with adolescent smoking. Tob Control. 2001;10(1):16-22. doi:10.1136/tc.10.1.16

15. King C, Siegel M. The Master Settlement Agreement with the tobacco industry and cigarette advertising in magazines. N Engl J Med. 2001;345(7):504-511. doi:10.1056/nejmsa003149

16. Hamilton WL, Turner-Bowker DM, Celebucki CC, Connolly GN. c. Tob Control. 2002;11(suppl 2):ii54-ii58. doi:10.1136/tc.11.suppl_2.ii54

17. Krupka LR, Vener AM, Richmond G. Tobacco advertising in gender-oriented popular magazines. Journal of Drug Education. 1990;20(1):15-29. doi:10.2190/6bww-rg2b-cv80-xyxn

18. Pucci LG, Siegel M. Exposure to brand-specific cigarette advertising in magazines and its impact on youth smoking. Prev Med. 1999;29(5):313-320. doi:10.1006/pmed.1999.0554

19. Kasujee N, Britton J, Cranwell J, Lyons A, Bains M. Portrayal of tobacco smoking in popular women's magazines: a content analysis. J Public Health. 2017;39(3):427-428. doi:10.1093/pubmed/fdw104

20. Public Library Graphic Novels Survey 2018. New York, NY: Library Journal; 2018. https://s3.amazonaws. com/WebVault/surveys/LJ\%202018\%20Graphic\%20 Novels\%20Survey\%20REPORT.pdf. Accessed May 25, 2020.

21. Tabachnick SE. The Graphic Novel and the Age of Transition: A Survey and Analysis. English Literature in Transition ,1880-1920. 2010;53(1):3-28. doi:10.2487/elt.53.1(2010)0050

22. Stewart R. Graphic reading. The Bookseller. https://www. thebookseller.com/feature/graphic-reading. Published October 29, 2003. Accessed March 2, 2020.

23. Le Duc D. Twenty First Century Graphic Novels. Belphegor. 2005;5(1):1-8.

24. Statista.com. Penetration of book reading in France in 2019, by book genre. https://www.statista.com/ statistics/415819/most-popular-book-genres-in-france/. Accessed May 1, 2020.

25. Schneider EF. A Survey of Graphic Novel Collection and Use in American Public Libraries. Evid Based Libr Inf Pract. 2014;9(3):68-79. doi:10.18438/b83s44

26. Royal Society of Literature. Literature in Britain today: an Ipsos MORI poll of public opinion commissioned by the Royal Society of Literature. London, UK: Royal Society of Literature; 2017.

27. Share of young people reading comics or comic books outside of class in the United Kingdom (UK) from 2005 to 2015. Statistica. https://www.statista.com/ statistics/299078/comics-reading-by-young-people-inthe-uk/. Accessed May 1st, 2020.

28. Evans C, Gaudet F. Comic Strip Readership. Culture études. 2012;2(2):1-8. doi:10.3917/cule.122.0001

29. Nyberg AK. How Librarians Learned to Love the Graphic Novel. In: Graphic Novels and Comics in Libraries and Archives: Essays on Readers, Research, History and Cataloguing. South Orange, NJ: Seton Hall University; 2010.

30. Strong Hansen K. In Defense of Graphic Novels. The English Journal. 2012;102(2):57-63.

31. Gluibizzi A. The Aesthetics and Academics of Graphic Novels and Comics. Art Documentation. 2007;26(1):2830 .

32. Coyne SM, Callister M, Stockdale L, Coutts H, Collier KM. "Just how graphic are graphic novels?" An examination of aggression portrayals in manga and associations with aggressive behavior in adolescents. Violence Vict. 2015;30(2):208-224. doi:10.1891/0886-6708.vv-d-1300012

33. Gibson R. Graphic illustration of impairment: science fiction, Transmetropolitan and the social model of disability. Med Humanit. 2018:46(1):12-21. doi:10.1136/medhum-2018-011506

34. Seko Y, Kikuchi M. Self-Injury in Japanese Manga: A Content Analysis. J Med Humanit. 2020. doi:10.1007/s10912-019-09602-9

35. Babaian CS, Chalian AA. "The thyroidectomy story": comic books, graphic novels, and the novel approach to teaching head and neck surgery through the genre of the comic book. J Surg Educ. 2014;71(3):413-418. doi:10.1016/j.jsurg.2013.11.008

36. Czerwiec MK, Huang MN. Hospice Comics: Representations of Patient and Family Experience of Illness and Death in Graphic Novels. J Med Humanit. 2017;38(2):95-113. doi:10.1007/s10912-014-9303-7

37. Imamura K, Kawakami N, Furukawa TA, Matsuyama Y, Shimazu A, Umanodan R, Kawakami S, Kasai K. Effects of an Internet-based cognitive behavioral therapy (iCBT) program in Manga format on improving subthreshold depressive symptoms among healthy workers: a randomized controlled trial. PLoS One. 2014;9(5):e97167. doi:10.1371/journal.pone.0097167

38. Lee YH, DeJong J. Depictions of Tobacco and Alcohol Use in Contemporary Japanese Shōnen Manga: A Content Analysis. J Health Commun. 2019;24(11):848-855. doi:10.1080/10810730.2019.1678704

39. Jimbo M. Japanese Manga and Smoking: Puffing Away. International Institute Journal. 2012;2(1). https:/quod.lib. umich.edu/cgi/p/pod/dod-idx/japanese-manga-and-smokingpuffing-away.pdf?c=iij;idno=11645653.0002.106;format=pdf. Accessed May 25, 2020.

40. Bouissou JM. Manga goes global. In: Critique internationale: Culture populaire et politique. 2000;7(1):1-36. doi:10.3406/criti.2000.1577 
41. Wong WS. Globalizing Manga: From Japan to Hong Kong and Beyond. Mechademia. 2006;1(1):23-45. doi:10.1353/mec.0.0060

42. Lefèvre P. The construction of national and foreign identities in French and Belgian postwar comics (19391970). Comicalités. https://journals.openedition.org/ comicalites/875. Accessed March 2, 2020.

43. Zanettin F. Translation, censorship and the development of European comics cultures. Perspectives. 2018;26(6):868884. doi:10.1080/0907676x.2017.1351456

44. Smoodin E. Cartoon and Comic Classicism: High-Art Histories of Lowbrow Culture. American Literary History. 1992;4(1):129-140. doi:10.1093/alh/4.1.129

45. Houghton F, O'Rourke-Scott L, Houghton S, O'Doherty D, McInerney D, Duncan B. Room 101: Are Gender Specific Cigarette Packets the Way Forward? Irish Journal of Medical Science. 2019;188(3):1081-1083. doi:10.1007/s11845-019-01971-3

46. O'Doherty D, Houghton F, McInerney D, Duncan B, Houghton D. EU Anti-Smoking Graphic Warnings on Cigarette packets: Semiotics and the issue of Gender Under-Representation. Irish Journal of Medical Science. 2019;188(3):1075-1077. doi:10.1007/s11845-018-1938-3

47. Danziger-Russell J. Girls and Their Comics: Finding a Female Voice in Comic Book Narratives. Ithaka, NY: Scarecrow Press; 2012. doi:10.1353/chq.2014.0015

48. Jorgensen A, Lechan A. Not Your Mom's Graphic Novels: Giving Girls a Choice Beyond Wonder Woman. Technical Services Quarterly. 2013;30(3):266-284. doi:10.1080/07317131.2013.785779

49. World Health Organization. European Tobacco Use: Trends Report 2019. Geneva, Switzerland: World Health Organization; 2019. https://www.euro.who.int/_data/ assets/pdf_file/0009/402777/Tobacco-Trends-ReportENG-WEB.pdf. Accessed May 25, 2020.

50. Snyder S, Capullo G, Miki D, Plascencia F. Batman Volume 5: Zero Year - Dark City. New York, NY: DC Comics; 2014.

51. Miéville C, Santolouco M, Lapham D, Burchielli R. Dial H Volume 1: Into You. New York, NY: DC Comics; 2013.

52. Ellis W, Robertson D. Transmetropolitan: Back On The Street. New York, NY: DC Comics; 2009.

53. Constantine J, Milligan P, Camuncoli G, Landini S, Bisley S. Hellblazer: Hooked. New York, NY: DC Comics; 2010.

54. Miller F. Sin City: A Dame to Kill For. Milwaukie, OR: Dark Horse Comics; 1995.

55. Brubaker E, Rucka G, Lark M, Gaudiano S. Gotham Central: Unresolved Targets. New York, NY: DC Comics; 2006.

56. Kirkman R, Adlard C, Rathburn C. The Walking Dead Volume 4: The Heart's Desire. Berkeley, CA: Image Comics Inc.; 2012.

57. Kirkman R, Adlard C, Rathburn C. The Walking Dead Volume 2: Miles Behind Us. Berkeley, CA: Image Comics Inc.; 2012.
58. Mills P, Ezquerra C, Flint H. ABC Warriors: The Shadow Warriors. Oxford, UK: Rebellion; 2009.

59. McKay SE, Lafrance D. War Brothers: The Graphic Novel. London, UK: Walker Books Ltd.; 2013.

60. Crawford MA, Tobacco Control Network Writing Group. Cigarette smoking and adolescents: messages they see and hear. Public Health Rep. 2001;116(Suppl 1): 203-215. doi:10.1093/phr/116.s1.203

61. Watson NA, Clarkson JP, Donovan RJ, Giles-Corti B. Filthy or fashionable? Young people's perceptions of smoking in the media. Health Education Research 2003;18(5):554-567. doi:10.1093/her/cyf039

62. Kraak VI, Story M. Influence of food companies' brand mascots and entertainment companies' cartoon media characters on children's diet and health: a systematic review and research needs. Obesity Review. 2015;16(2):107-126. doi:10.1111/obr.12237

63. Mantzari E, Vasiljevic M, Turney I, Pilling M, Marteau T. Impact of warning labels on sugar-sweetened beverages on parental selection: An online experimental study. Prev Med Rep. 2018;12:259-267. doi:10.1016/j.pmedr.2018.10.016

\section{CONFLICTS OF INTEREST}

The authors have completed and submitted the ICMJE Form for Disclosure of Potential Conflicts of Interest and none was reported.

\section{FUNDING}

There was no source of funding for this research.

PROVENANCE AND PEER REVIEW

Not commissioned; externally peer reviewed. 